\title{
Histomorfometri Granulosit Bibit Sapi Bali di Nusa Penida
}

\section{(HISTOMORPHOMETRY OF GRANULOCYTES BALI CATTLE SEEDLINGS IN NUSA PENIDA)}

\author{
Oktavyan Loys Mami ${ }^{1 *}$, Ni Ketut Suwiti ${ }^{2}$, Ni Luh Eka Setiasih ${ }^{3}$ \\ ${ }^{1}$ Mahasiswa Program Profesi Dokter Hewan, Fakultas Kedokteran Hewan Universitas \\ Udayana, Jl. PB. Sudirman, Denpasar, Bali; ${ }^{2}$ Laboratorium Histologi Veteriner, Fakultas \\ Kedokteran Hewan, Universitas Udayana, Jl. PB. Sudirman, Denpasar, Bali. \\ *Email: oktavyanloys@gmail.com
}

\begin{abstract}
Abstrak
Penelitian ini bertujuan untuk mengetahui histomorfometri granulosit bibit sapi bali di Nusa Penida. Sebanyak 50 ekor sapi bali betina diambil darahnya melalui vena jugularis menggunakan venoject. Selanjutnya dibuat apusan darah dengan metode slide, sampel difiksasi dan diwarnai dengan pewarnaan Giemsa. Histomorfometri granulosit yakni neutrofil,eosinofil,dan basofil diukur dengan menggunakan mikroskop Axio Imaginer Zeiss 2 dan software ZEN 2012. Data yang diperoleh dianalisis dengan descriptive statistics. Hasil penelitian menunjukan rerata diameter neutrofil yaitu $9,1 \pm 1,4 \mu \mathrm{m}$ dengan kisaran 6-11, eosinofil 8,9 $\pm 1,6 \mu \mathrm{m}$ dengan kisaran 5-13 $\mu \mathrm{m}$, dan basofil 8,9 $\pm 1,7 \mu \mathrm{m}$ dengan kisaran 5$11 \mu \mathrm{m}$.
\end{abstract}

Kata kunci: sapi bali; histomorfometri; granulosit; Nusa Penida

\begin{abstract}
The aim of this research was to find out the granulocyte histomorphometry of bali cattle in Nusa Penida. The blood samples are collected from 50 female bali cattle. Blood collection is carried out through the jugular vein using venoject. Making blood smears using the slide method was done at the sampling site, followed by fixation and staining of Giemsa. The measurement of granulocyte diameter was carried out using the Axio Imager Zeiss 2 microscope and ZEN 2012. software The data obtained were analyzed by descriptive statistics. The mean of granulocyte histomorphometry in Nusa Penida was $9.1 \pm 1,4 \mu \mathrm{m}$ neutrophils, $8.9 \pm 1,6 \mu \mathrm{m}$ eosinophils, and $8.9 \pm 1,7 \mu \mathrm{m}$ basophils with a range of $6-11 \mu \mathrm{m}$ in neutrophils, $5-13 \mu \mathrm{m}$ in eosinophils, and 5-11 $\mu \mathrm{m}$ in basophils.
\end{abstract}

Keywords: bali cattle; histomorphometry; granulocytes; Nusa Penida

\section{PENDAHULUAN}

Nusa Penida dinyatakan sebagai pusat konservasi dan pengembangan sapi bali karena potensi sapi bali yang ada di daratan maupun Nusa Penida dikenal sebagai sapi bali murni (Pure Breed) yang patut dijaga kemurniannya (RPJPD, 2005; Besung et al., 2019). Populasi ternak sapi bali di Kecamatan Nusa Penida tahun 2008-2012 mencapai 126.052 ekor. Struktur populasi sapi bali di Kecamatan Nusa Penida terbagi tiga, yaitu pedet berjumlah 8.398 ekor, dara berjumlah 7.156 ekor, dan dewasa berjumlah 11.793 ekor (Dinas Peternakan Perikanan dan Kelautan Kabupaten Klungkung, 2012).
Sapi bali memberikan kontribusi yang sangat besar dalam penyediaan daging di Indonesia dan merupakan sumber daya genetik asli Indonesia. Sapi bali dapat menghasilkan bibit sapi yang bermutu karena keunggulannya yang tidak dimiliki oleh bangsa sapi lainnya di dunia (Laksmi et al., 2019). Adapun keunggulan sapi bali yaitu dapat hidup pada kondisi yang kurang menguntungkan sehingga dikenal sebagai sapi perintis (Zulkharnaim et al., 2010), memiliki kualitas daging yang baik dengan persentase lemak yang rendah (Bugiwati 2007; Sarassati dan Agustina, 2015; Agustina et al., 2017), tingkat fertilitas tinggi yaitu 80-82\% (Noor et al. 2001), 
kemampuan daya cerna pakan baik, memiliki resistensi tinggi terhadap kutu dan penyakit, serta kemampuan kerja yang baik (Siswanto, 2011).

Resistensi tubuh sapi bali sangat tergantung dengan sistem pertahanan tubuh, terutama leukosit yang merupakan unit yang aktif. Pembentukan leukosit terjadi di sumsum tulang (granulosit dan monosit serta sedikit limfosit) dan sebagian lagi di jaringan limfe (limfosit dan sel-sel plasma) (Guyton dan Hall, 2006). Ada dua jenis leukosit yaitu granulosit dan agranulosit. Granulosit adalah sel yang pada sitoplasmanya terdapat granul dan pada inti sel terdapat lobus atau segmen. Sel granulosit terdiri atas neutrofil, basofil, dan eosinofil.Agranulosit adalah sel yang pada sitoplasmanya tidak terdapat granul dan tidak terdapat lobus atau segmen pada inti. Sel agranulosit terdiri atas limfosit dan monosit (Samuelson, 2007).

Neutrofil memiliki 2 bentuk yakni menyerupai band/pita (imatur, belum matang, belum dewasa) dan yang memiliki lobus/ segmen (matur, matang, dewasa) (Reece, 2005). Neutrofil memainkan peran sentral dalam sistem imun bawaan (Nathan, 2006). Neutrofil berperan sebagai garis pertahanan pertama (first line of defense) dalam melawan infeksi mikroba/ bakteri. Mikroba/ bakteri yang masuk ke dalam tubuh akan difagositosis oleh neutrofil (Brinkmann et al. 2004). Leukosit eosinofil sapi bali intinya terdiri dari dua lobus yang dipisahkan oleh bahan inti dan butir-butir kromatinnya tidak begitu padat bila dibandingkan dengan inti neutrofil. Granulnya bersifat asidofil atau berwarna merah dengan eosin. Intinya bergelambir dua yang dikelilingi oleh butir-butir asidofil yang cukup besar. Granulosit eosinofil dapat bergerak aktif dan sedikit fagositik, hanya berperan sedikit dalam sistem pertahanan terhadap infeksi mikroorganisme (Putra et al., 2015). Basofil sedikit lebih kecil dari neutrofil, berdiameter $10 \mu \mathrm{m}$ pada apusan darah.
Granul spesifiknya relatif sedikit dan lebih besar daripada eosinofil (Fawcett, 2002).

Ukuran dari neutrofil, eosinofil dan basofil dapat dipengaruhi oleh berbagai hal, salah satunya adalah spesies, oleh karena itu perlu dipelajari bagaimanakah histomorfometri ketiga sel tersebut. Histomorfometri merupakan suatu metode pengukuran sel atau jaringan. Untuk mempelajari perubahan bentuk dan aktifitas dari sel maka digunakan histomorfometri. Pengukuran dari histomorfometri meliputi pengukuran volume, ketebalan, panjang, dan lebar suatu sel atau jaringan (Eriksen $e t$ al., 1994).

\section{METODE PENELITIAN}

\section{Sampel Penelitian}

Penelitian ini menggunakan ulasan darah dari 50 ekor bibit sapi bali betina berumur di atas 1 tahun yang dipelihara di Nusa Penida. Seluruh sapi bali yang dijadikan sampel dipastikan sehat secara klinis.

\section{Rancangan Penelitian}

Penelitian ini merupakan penelitian deskriptif kualitatif dengan melihat gambaran histologi dan kuantitatif yang dilakukan dengan pengukuran diameter sel granulosit. Sampel darah diambil dari 50 ekor sapi bali betina bibit yang sehat secara klinis di Kecamatan Nusa Penida, Kabupaten Klungkung, Provinsi Bali. Sampel diambil melalui vena jugularis dengan menggunakan venoject, kemudian dibuat apusan darah.

\section{Pembuatan Sediaan Ulas Darah}

Metode yang digunakan dalam pembuatan apusan darah adalah metode slide dengan cara sebagai berikut. Gelas obyek dibersihkan dengan alkohol $95 \%$ dan dikeringkan. Darah diteteskan ke salah satu ujung gelas obyek dan segera dibuat sediaan ulasan darah (Utama, et al. 2013). Setelah dikeringkan dengan cara mengangin-anginkannya, sediaan ulas kemudian difiksasi menggunakan larutan methanol absolut selama lima menit. Objek 
glass dikeringkan dan diwarnai dengan metode pewarnaan Giemsa 10\% (Houwen, 2000). Takaran pewarnaan Giemsa adalah $1 \mathrm{ml}$ Giemsa ditambah dengan $9 \mathrm{ml}$ aquades sebagai pengencer dengan lama pewarnaan 15-20 menit.

\section{Pengamatan Sel Darah}

Setelah sediaan kering kemudian di simpan dan diamati di laboratorium menggunakan mikroskop dengan pembesaran 1000x (Weiss dan Wardrop, 2010). Pengukuran granulosit dilakukan dibawah mikroskop dengan pembesaran lensa obyektif 100x dan lensa okuler 10x dibantu dengan meneteskan minyak Emersi untuk mengurangi adanya bias. Pengamatan pengukuran granulosit menggunakan mikroskop Axio Imager Zeiss 2 dan software ZEN 2012. Penelitian dilakukan di Laboratorium Histologi Fakultas Kedokteran Hewan Universitas Udayana.

\section{Analisis Data}

Pengukuran granulosit dianalisis secara deskriptif kuantitatif dengan program software SPSS versi 17.0.

\section{HASIL DAN PEMBAHASAN}

Hasil

Berikut ini gambaran dan data hasil pengukuran rerata diameter granulosit bibit sapi bali di Nusa Penida yang telah diperiksa.

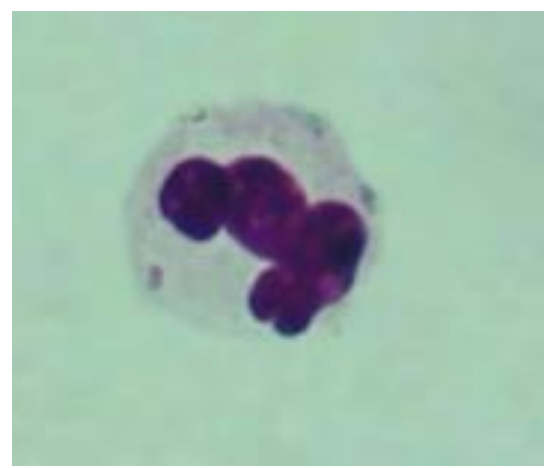

Gambar 1 Struktur histologi neutrofil bibit sapi bali di Nusa Penida

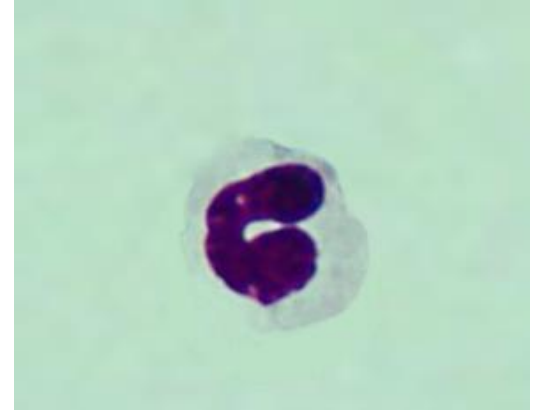

Gambar 2 Struktur histologi eosinofil bibit sapi bali di Nusa Penida

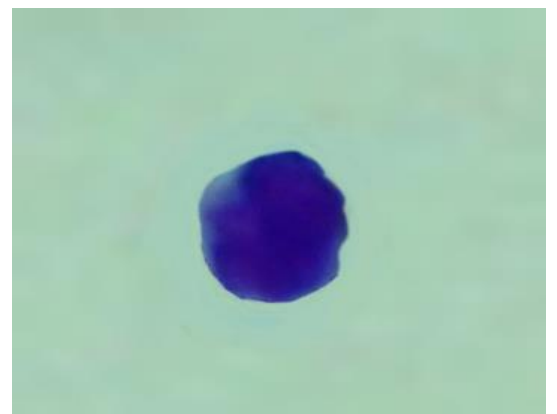

Gambar 3 Struktur histologi basofil bibit sapi bali di Nusa Penida

\section{Pembahasan}

Hasil pengamatan terhadap struktur histologi neutrofil (Gambar 1) menunjukkan inti neutrofil tidak berbentuk bulat melainkan berlobus yang jumlahnya dua sampai lima lobus. Dinding nukleus tampak dengan jelas dan sitoplasma tampak jelas mengelilingi nukleus. Inti kromatin terlihat pekat dan mengelompok, serta memiliki granul halus pada sitoplasma (Rahayu et al., 2016). Sitoplasma neutrofil bibit sapi bali di Nusa Penida terlihat agak transparan karena granulya kecil dan berwarna netral.

Neutrofil merupakan granulosit yang paling besar ditemukan pada kebanyakan hewan. Neutrofil memiliki fungsi sebagai garis pertahanan pertama (first line of defense) terhadap serangan mikroorganisme khususnya melawan infeksi bakteri, trauma jaringan atau pemicu sinyal inflamasi lainnya (Putra et al., 2015). 
Gambaran histologi neutrofil dapat dipengaruhi oleh faktor pakan yang diberikan (Suwiti et al., 2012), Sitoplasma sel neutrofil yang diberikan mineral terlihat lebih besar dan jelas. Hal ini disebabkan oleh faktor pemberian mineral yang ditambahkan pada pakan. Mineral berpengaruh terhadap struktur sel-sel sistem pertahanan. Hal ini membuktikan bahwa faktor pakan dapat mempengaruhi ukuran granulosit khususnya neutrophil (Besung et al., 2019).

Gambaran histologi eosinofil (Gambar 2) adanya variasi nukleus berlobus dua dengan bentuk tidak beraturan. Sitoplasma tampak jelas namun dinding eosinofil tidak begitu jelas. Inti eosinofil mirip dengan inti neutrofil, perbedaanya inti eosinofil memiliki dua lobus dan sitoplasmanya berwarna merah. Hal tersebut dikarenakan lobus biasanya tertutup oleh granul. Granul eosinofil pada ruminansia berwarna merah cerah dikarenakan menyerap warna merah eosin (bersifat asidofil) (Rahayu et al., 2016).

Struktur histologi basofil (Gambar 3) terdiri atas dua lobus yang seolah-olah terlihat menjadi satu lobus dengan bentuk tidak beraturan (ireguler). Granul pada sitoplasma berwarna biru tua atau ungu agak cerah karena bersifat basofilik dan menutupi inti (Putra et al., 2015).

Hasil penelitian yang diperoleh yaitu histomorfometri granulosit bibit sapi bali di Nusa Penida cukup bervariasi dilihat dari rerata diameter yang diteliti. Neutrofil yang jumlahnya paling banyak ditemukan diantara granulosit lainnya menunjukkan rerata diameter sebesar $9,1 \mu \mathrm{m}$, eosinofil $8,9 \mu \mathrm{m}$, dan basofil $8,9 \mu \mathrm{m}$. Adapun rerata granulosit bibit sapi bali di Nusa Penida disajikan pada Tabel 1 di bawah ini.

Tabel 1 Rerata diameter granulosit sapi bali di Nusa Penida

\begin{tabular}{lcl}
\hline Granulosit & Range & Rerata \pm SD \\
\hline Neutrofil & $6-11$ & $9,1 \pm 1,4$ \\
\hline Eosinofil & $5-13$ & $8,9 \pm 1,6$ \\
\hline Basofil & $5-11$ & $8,9 \pm 1,7$ \\
\hline
\end{tabular}

Hasil pengukuran yang diperoleh yaitu histomorfometri granulosit bibit sapi bali di Nusa Penida cukup bervariasi dilihat dari rerata diameter yang diteliti. Neutrofil yang jumlahnya paling banyak ditemukan diantara granulosit lainnya menunjukan rerata diameter sebesar $9,1 \mu \mathrm{m}$, eosinofil $8,9 \mu \mathrm{m}$, dan basofil $8,9 \mu \mathrm{m}$.

\section{SIMPULAN DAN SARAN}

\section{Simpulan}

Neutrofil bibit sapi bali di Nusa Penida memiliki rerata ukuran diameter lebih besar dibandingkan dengan $(9,1 \pm 1,4 \mu \mathrm{m})$ eosinofil $(8,9 \pm 1,6 \mu \mathrm{m})$ dan basofil $(8,9 \pm 1,7$ $\mu \mathrm{m})$

\section{Saran}

Perlu dilakukan penelitian lebih lanjut mengenai histomorfometri leukosit granulosit sapi bali di Nusa Penida dengan menambah variabel jenis kelamin, umur dan lain-lain

\section{UCAPAN TERIMAKASIH}

Ucapan Terimakasih kepada pemerintah Dinas Peternakan Kabupaten Klungkung yang telah mendukung terlaksananya penelitian ini.

\section{DAFTAR PUSTAKA}

Agustina KK, Cahya IMRD, Widyantara GM, Swacita IBN, Dharmayudha AAGO, Rudyanto MD. 2017. Nilai gizi dan kualitas fisik daging sapi bali berdasarkan jenis kelamin dan umur. Buletin Vet. Udayana. 9(2): 156-163.

Besung INK, Watiniasih NL, Mahardika GNK, Agustina KK, Suwiti NK. 2019. Mineral levels of Bali cattle (Bos javanicus) from different types of land in Bali, Nusa Penida, and Sumbawa Islands (Indonesia). Biodiversitas. 20(10): 2931-2936.

Brinkmann V, Reichard U, Goosmann C, Fauler B, Uhlemann Y,Weiss DS, Weinrauch Y, Zychlinsky A. 2004. Neutrophil extracellular traps kill bacteria. Sci. 303: 1532-1535. 
Bugiwati SRA. 2007. Body dimension growth of calf bull in Bone and Baru District, South Sulawesi. J. Sains. Teknol. 7: 103-108.

Dinas Peternakan Perikanan Dan Kelautan Kabupaten Klungkung. 2014. Laporan tahuan data produksi bali bidang peternakan perikanan dan kelautan. Pemerintah Kabupaten Klungkung, Provinsi Bali.

Eriksen EF, Axelrod DW, Melsen F, Obrant K. 1994. Bone histomorfometry. New York, USA: Raven Press.

Fawcett DW. 2002. Buku ajar histologi. A textbook of histology, $1^{\text {st }}$ Ed. Tambayong dan H. Hartanto. EGC Press. Jakarta.

Guyton AC, Hall JE. 2006. Textbook of medical physiology. $11^{\text {th }}$ Ed. Elsevier Inc, Philadelphia.

Houwen B. 2000. Blood film preparation and staining procedures. Lab. Hematol. 6: 1-7.

Laksmi DNDI, Trilaksana IGNB, Darmanta RJ, Darwan M, Bebas IW, Agustina KK. 2019. Correlation between body condition score and hormone level of Bali cattle with postpartum anestrus. Indian J. Anim. Res. 2019(53): 1599-1603.

Nathan C. 2006. Neutrophils and immunity: challenges and opportunities. Nat. Rev. Immunol. 6: 173-182.

Noor RR, Farajallah A, Karmita M. 2001. The purity test of bali cattle by haemoglobin analysis using the isoelectric focusing method. Hayati. 8: 107-111.
Putra IE, Suwiti NK, Suatha IK. 2015. Identifikasi sel granulosit leukosit pada sapi bali. Skripsi. Universitas Udayana. Denpasar, Bali.

Rahayu NLSS, Suwiti NK, Suastika P. 2016. Struktur histologi dan histomorfometri granulosit pada sapi bali pasca pemberian mineral. Buletin Vet.Udayana. 8(2): 151-158.

Reece WO. 2005. Functional anatomy and Physiology of Domectic Animals. $3^{\text {rd }}$ Ed. Baltimore, Maryland USA: Lipincott Williams \& wilkins.

RPJPD. 2005. Rencana pembangunan jangka panjang daerah Kabupaten Klungkung Tahun 2005-2025. Peraturan Daerah Kabupaten Klungkung.

Sarassati T, Agustina KK. 2015. Kualitas daging sapi wagyu dan daging sapi bali yang disimpan pada suhu-19 ${ }^{\circ} \mathrm{C}$. Indonesia Vet. Med. 4(3): 178-185.

Samuelson DA. 2007. Textbook of veterinary histologi. China: Saunders, an imprint of Elsevier Inc.

Siswanto. 2011. Gambaran sel darah merah sapi bali (studi rumah potong). Buletin Vet. Udayana. 3(2): 99-105.

Utama IH, Kendran AAS, Widyastuti SK, Virgania P, Sene SM, Kusuma WD, dan Arisandi BY. 2013. Hitung diferensial dan kelainan-kelainan sel darah sapi bali. J. Vet. 14(4): 462-466.

Weiss DJ, Wardrop KJ. 2010. Schalm's veterinary hematology. $6^{\text {th }} \quad$ Ed. Blackwell Publishing Ltd. Singapore.

Zulkharnaim, Jakaria, Noor RR. 2010. Identification of genetic diversity of growth hormone receptor (GHR|Alu I) gene in bali cattle. J. Med. Pet. 33: 8187. 